\title{
Liver metabolic activities of Pasundan cattle induced by irradiated chitosan
}

\author{
ANDI MUSHAWWIR ${ }^{1, \bullet}$, JOHAR ARIFIN ${ }^{2}$, DARMAWAN DARWIS ${ }^{3}$, TITA PUSPITASARI ${ }^{3}$, \\ DEWI SEKAR PENGERTENI ${ }^{3}$, NUNUNG NURYANTHI ${ }^{3}$, RONNIE PERMAN ${ }^{1}$ \\ ${ }^{1}$ Animal Physiology and Biochemistry Laboratory, Department of Animal Nutrition and Feed Technology, Faculty of Animal Science, \\ Universitas Padjadjaran. J1. Raya Bandung-Sumedang Km. 21, Jatinangor, Sumedang 45363, West Java, Indonesia. Tel.: +62-22-7798241, \\ •email: mushawwir.unpad@gmail.com \\ ${ }^{2}$ Animal Genetic and Biometric Laboratory, Department of Animal Production, Faculty of Animal Science, Universitas Padjadjaran. Jl. Raya Bandung- \\ Sumedang Km. 21, Sumedang 45363, West Java, Indonesia \\ ${ }^{3}$ Center for Isotope and Radiation Application, Indonesian National Nuclear Energy Agency. Jl. Lebak Bulus Raya No. 49, Jakarta Selatan 12440, \\ Jakarta, Indonesia
}

Manuscript received: 16 September 2020. Revision accepted: 2 November 2020.

\begin{abstract}
Mushawwir A, Arifin J, Darwis D, Puspitasari T, Pengerteni DS, Nuryanthi N, Perman R. 2020. Liver metabolic activities of Pasundan cattle induced by irradiated chitosan. Biodiversitas 21: 5571-5578. A total of one hundred and twenty-five, 2-3 year old male Pasundan cattle were used as livestock samples during the three months of this research. They were selected from the local cattle breeding and development center in Ciamis. The animal samples were randomly allocated to 5 treatment groups. One group served as the control, or without irradiated chitosan, while the others were used as treatment in varying levels. Each treatment group involved five replicates with 25 Pasundan bulls per treatment i.e five Pasundan bulls per replication. Each group was provided with the following rations: $\mathrm{C} 0=$ Control group, without IC $(0 \mathrm{ppm}$ IC); $\mathrm{C} 1=350 \mathrm{ppm}$ Irradiated Chitosan (IC); C2 = $400 \mathrm{ppm}$ IC; $\mathrm{C} 3=450 \mathrm{ppm}$ IC; and $\mathrm{C} 4=500 \mathrm{ppm}$ IC. Irradiated chitosan was obtained through the following steps: extraction, deacetylation, and irradiation of chitin using gamma rays. Five $\mathrm{mL}$ of blood samples were collected from each bull at the beginning of each month of this experiment, which totaled three months. The blood samples were sucked from the tail/coccygeal vein using a sterilized syringe and vacuum tube containing K3EDTA. The plasma was used to determine the concentration of parameters related to liver metabolism through an automatic biochemical analyzer Kenza 240TX model from Biolabo, using a commercial kit. Each procedure was followed based on the Biolabo kit (Franch) and Randox kit (UK). This study showed that IC reduces the activity of glycogenolysis and glycolysis, but is accompanied by improvements in the biochemical conditions of liver cells. This is a favorable condition for the metabolism of Pasundan bulls in order to enhance their growth and reproduction.
\end{abstract}

Keywords: Cattle, irradiated chitosan, liver, metabolic

\section{INTRODUCTION}

Pasundan cattle (or Rancah cattle) are one of the local ruminants that can be reared in Indonesia. These cattle are a cross of Bos javanicus x Bos indicus. These are local cows that have been growing in West Java for a long time, especially in areas with low topography. From the climatological aspect, they can adapt to Indonesian tropical climates (Sutarno and Setyawan 2015, 2016). However, Pasundan cattle appear to have many deficiencies in terms of performance, i.e. growth and reproduction, when compared to local crossbred cattle. Aamir et al. (2010) and Adrial (2010), observed that local cattle in Indonesia do not show high growth. The Pasundan cow performance was published by the Department of Animal Husbandry in 2013, and its reproductive traits include: First calving at 30-40 months, sex maturity at 25-30 months, gestation length 8.5-10.0 months, first estrus 18-24 months, estrus periods (18-24 days) and calving interval (1.1-1.3 years). The carcass traits of Pasundan cattle such as water holding capacity ranges between 23-30\%, cooking loss 25-45\%, tenderness $35-96 \mathrm{~mm} / 10 \mathrm{~s} / \mathrm{g}$. The slaughter weight, hot carcass, and dressing percentage of Pasundan bull weights are $240.40 \mathrm{~kg}, 127.20 \mathrm{~kg}$, and $53.02 \%$, respectively (Aamir et al. 2010; Department of Animal Husbandry, 2013; Nugraha et al. 2016).

Researchers have discovered various strategies for improving the performance of cattle. Abdullah et al. (2007), stated that crossbreeding techniques can improve the genetic quality of livestock, and the reproductive system is enhanced by inducing the performance of their hormonal system (Khan et al. 2015). However, no report of metabolic induction studies has as a good strategy for Pasundan cattle. The induction of metabolism using natural extracts is the first step in the application of nutrigenomics for ruminant development.

The natural extracts added to the feed showed positive results for increased metabolism, which was related to changes in gene expression within cells. He et al. (2019) demonstrated the effectiveness of garlic extract on gene expression in increasing immunity and performance of experimental animals. The same results were obtained by Tian et al. (2015, 2016); Adriani et al. (2015); Kusmayadi et al. (2018); Mushawwir et al. (2018); Soisuwon and Chauychuwing (2013) and Kamil et al. (2020), that plant extract improves the performance of nutrient absorption 
and metabolic rate in the liver and also increases livestock growth.

Chitosan is one of the most widely used natural extract ingredients. It originates from the exoskeleton of arthropods such as crabs, shrimp, insects, and other species in the crustacean family (Bueter et al. 2014; Carrol et al. 2016). It possesses multifunctional properties, including antibacterial (Cai et al. 2014; Allen et al. 2015; Moreno et al. 2019) and antioxidant characteristics (Yarrus et al. 2012; Qiu et al. 2018; Araujo et al. 2015). Chitosan is a linear polysaccharide in form of $\beta$ - $(1,4)$-2-amino-2-deoxyD-glucopyranose, where its structure is similar to glycosaminoglycans. Furthermore, it is a hetero-polymer of glucosamine (2-amino-2-deoxy- $\beta$-D-glucose) which binds to $\beta-1,4$ polymer and contains $\mathrm{N}$-acetyl-glucosamine. New techniques for chitosan processing are continuously developed, and one of these (Darwis et al. 2014) is irradiated chitosan. There are no previous research on the application of irradiated chitosan in animals, especially cattle.

Irradiated chitosan (IC) produced through the application of nuclear technology, has better quality due to the shorter nature of the glucosamine polymer, therefore the molecular weight is lighter. This irradiated chitosan is absorbed into livestock tissue cells to interact with the biochemical metabolic system in the liver. This study aims to determine the effect of irradiated chitosan on the metabolism of Pasundan bull liver cells.

\section{MATERIALS AND METHODS}

\section{Study area}

This research was carried out in Ciamis District, West Java, which has become a center for the development and breeding of Pasundan cattle in the West Answer Province, Indonesia. This was the main reason for selecting this location, in order to facilitate the use of Pasundan cattle as research samples. Moreover, homogeneous samples can be determined according to their biological aspects. The research location is shown in Figure 1.

\section{Experimental design}

Animal samples and treatment

A total of one hundred and twenty-five, 2-3 year old male Pasundan cattle were used as livestock samples for the three months of this research. They were selected from the local cattle breeding and development center in Ciamis. The animal samples were randomly allocated to 5 treatment groups and placed in the colony pen, measuring $4 \times 3 \mathrm{~m}$. Each pen was allocated to a single group. In this study, 25 colony cages were used in an open house with a tail to tail system. The average housing temperature was $25-32^{\circ} \mathrm{C}$, while the relative humidity was maintained between $74-$ $80 \%$ during the experimental period,. The animals were provided with water and food ad libitum.

The animal samples were randomly allocated to 5 treatment groups: control or without IC, and the other group as a treatment group at various IC levels. Each treatment group involved five Pasundan bulls per replication. The rations and treatment provided include the following: (i) C0: Control group, without IC (0 ppm IC), (ii) C1: $350 \mathrm{ppm}$ Irradiated Chitosan (IC), (iii) C2: 400 ppm IC, (iv) C3: 450 ppm IC, (v) C4: 500 ppm IC.

\section{Preparation of Chitosan Irradiation (IC)}

Irradiated chitosan was obtained through the following procedure:

\section{Extraction of chitin}

The extraction of chitin from shrimp shells includes two stages, namely: deproteination and demineralization. These involved the removal of protein using $1 \mathrm{~N} \mathrm{NaOH}$ solution at room temperature for 24 hours. Afterward, the shell was rinsed with water to a neutral $\mathrm{pH}$. The deproteinated shell was then suspended in $1 \mathrm{~N}$ hydrochloric acid solution $(\mathrm{HCl})$ at room temperature for 24 hours to remove mainly minerals calcium carbonate. The residue collected and washed to neutral in tap water. Lastly, it was dried in the sun to obtain chitin.

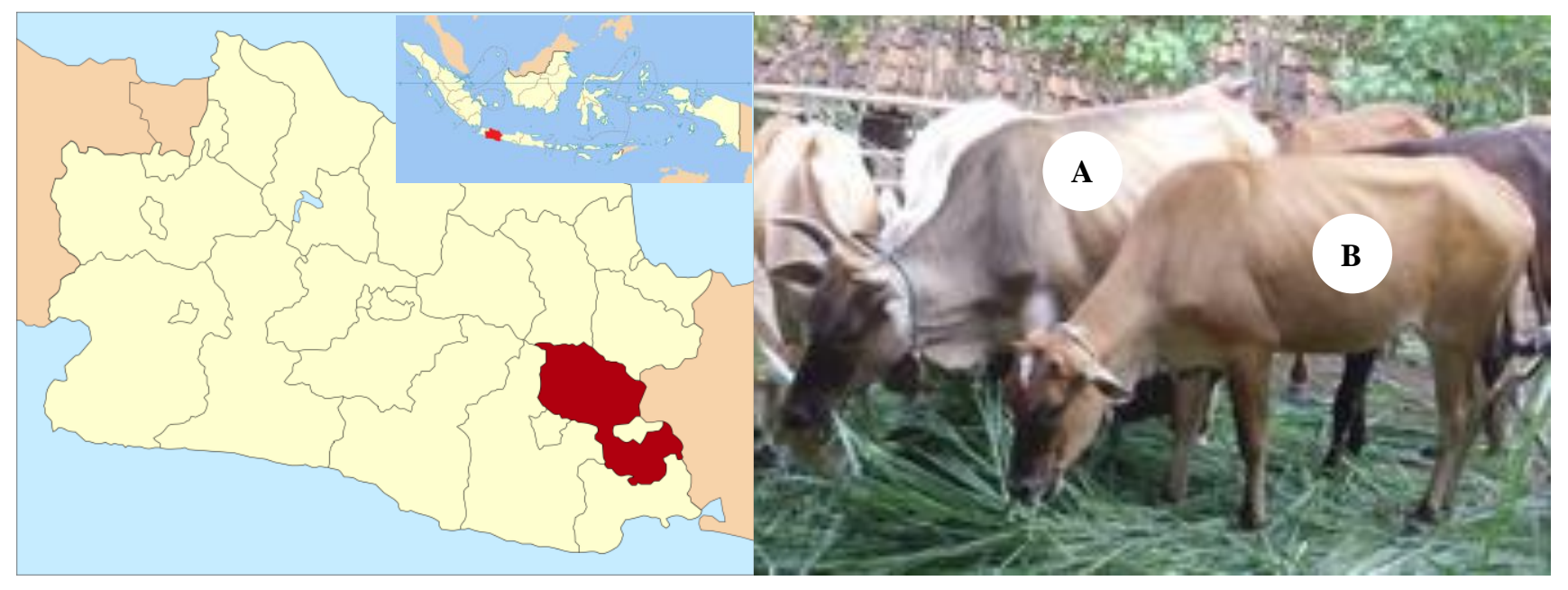

Figure 1. Research location of Pasundan cattle in Ciamis District, West Java, Indonesia. A. Male, B. Female of Pasundan cattle 


\section{Chitin deacetylation}

Before the deacetylation process, a mixer was used to cut the chitin into $1 \mathrm{~mm}$ flakes. Deacetylation of chitin was carried out under alkaline conditions using $50 \% \mathrm{NaOH}$ solution at $90^{\circ} \mathrm{C}$. Afterward, the chitosan was collected and washed using hot water and soaked in distilled water for 1 hour to obtain a neutral $\mathrm{pH}$.

\section{Irradiation}

Low molecular weight chitosan was produced by irradiating its flakes using $\mathrm{Co}^{60}$ gamma rays at a dose rate of $10 \mathrm{kGy} /$ hour.

\section{The technique of treatment and basal ration}

Irradiated chitosan (IC) was dissolved in $1 \mathrm{~L}$ of water, which obtained doses or concentrations of 350,400,450, and $500 \mathrm{ppm}$. Afterward, each experimental animal was fed $2 \mathrm{~kg}$ of concentrate according to the treatment group. This IC + concentrate was administered daily before the provision of drinking water and forage. The concentrate composition is shown in Table 1.

\section{Sample collection and analysis}

Five $\mathrm{mL}$ of blood samples were collected from each Pasundan bulls at the beginning of each month. They were sucked from the coccygeal vein using a sterilized syringe and vacuum tube containing K3EDTA. Slide alcohol $70 \%$ was applied on the medial side of the tail before and after blood collection to prevent pathogenic infection.

The blood samples collected were also centrifuged to separate the plasma. The plasma was used to determine the concentration of parameters related to liver metabolism via an automatic biochemical analyzer from Biolabo Kenza 240TX model, using a commercial kit. Each procedure of the analysis was followed based on the Biolabo kit (French) and Randox kit (UK). The experimental protocol and the animal samples followed good animal practice Furthermore the authors declare that there are no competing interests.

\section{Data analysis}

The one-way analysis of variance (ANOVA) was used to analyze the liver metabolic levels. The SPSS software Version IBM 21 was used to obtain a completely randomized design. The difference between the mean of all treatments was obtained using Duncan's multiple range tests (SPSS IBM, 2010) at a 95\% significance level or $\alpha=5 \%$.

Table 1. Composition of nutrient concentrates used during the study

\begin{tabular}{lc}
\hline Nutrients* & $(\boldsymbol{\%})$ \\
\hline Carbohydrate & 12 \\
Dry matter & 88 \\
Crude protein & 18 \\
True digestibility nutrient & 75 \\
Crude fat & 7 \\
Crude fiber & 7 \\
Neutral detergent fiber & 30 \\
Calcium & 0.7 \\
Phosphorus & 0.6 \\
\hline
\end{tabular}

Note: *Local Cattle Breeding Centre, Ciamis (2019).

\section{RESULTS AND DISCUSSION}

\section{Glycogenolysis pathway}

The effect of various levels of IC on the concentration of glycogenolysis pathway metabolites in the Pasundan bulls is shown in Table 2.

In this experiment, Pasundan bulls were housed in cages with and without IC treatment. The average glycogen level in the sample animals without IC was $0.97 \mathrm{mg} / \mathrm{g}$ (Table 2). The increase in glycogen levels in the IC-treated Pasundan bulls group was significant $(\mathrm{P}<0.05)$, starting with IC levels of 450 and 500 ppm, namely 1.32 and 1.48 , respectively. These results indicate that during treatment, a minimum of 450 ppm causes a decrease in glycogen breakdown in liver cells. Meanwhile, glycogen decrease in the group without IC treatment caused the degradation or catabolism of glycogen (glycogenolysis). This catabolism also occurred in the Pasundan bulls group treated with 400 ppm IC.

The effectiveness of IC was observed in the group that was administered with 450 and 500 ppm IC. This was shown by the glycogen levels in the livestock sample group, which was significantly $(\mathrm{P}<0.05)$ higher than the cattle group without IC treatment, and with IC treatment at 350 and $400 \mathrm{ppm}$. The results of this study indicate that IC administration reduces the rate of energy supply from alternative pathways, such as glycogenolysis (Mushawwir et al. 2010, 2011; Slimen et al. 2016). Previous research has also shown that natural extracts reduce glycogenolysis in ruminants (Aziz et al. 2012; Ao et al. 2020; Paiva et al. 2016; Fabris et al. 2017; Valle et al. 2017), and decreases glucagon activity (Soisuwon et al. 2013; Adrian and Mushawwir 2020); Kamil et al. 2020).

The intermediate metabolites such as glucose 1phosphate, glucose 6-phosphate, and the enzymes involved, including glycogen phosphorylase, phosphoglucomutase, and glucose 6-phosphatase, during glycogenolysis, appeared to be increased in the livestock group not given IC. Increasing the level of these intermediates occurs due to an increase in glycogenolysis. Previous research also showed an increased profile of intermediate metabolites with the same profile (Tanuwiria et al. 2011; Gray et al. 2015; Mingoti et al. 2016; Siskos et al. 2017).

The increased levels of intermediates and enzymes involved in the glycogenolysis pathway occurred due to the increased rate of glycogen catabolism. The group of livestock samples that were not given IC showed a significant increase in intermediate metabolites $(\mathrm{P}<0.05)$. In Table 2, it is observed that the level of the intermediate compound glucose 1-phosphate is $0.42 \mathrm{IU} / \mathrm{dL}$, was significantly higher $(\mathrm{P}<0.05)$ in the livestock group given $500 \mathrm{ppm}$ IC, namely $0.20 \mathrm{IU} / \mathrm{dL}$, likewise, for the intermediate compound glucose 6-phosphate 0.31 (without IC) to $0.22 \mathrm{IU} / \mathrm{dL}(500 \mathrm{ppm} \mathrm{IC})$. The same results also occurred for the catalytic enzymes of glycogenolysis. The results of previous studies showed an increase in the levels of the enzyme catalyst for the glycogenolysis pathway with increased glycogen biocatalyst activity (Holt et al. 2010; Odore et al. 2011; Monteiro et al. 2016). The administration of natural extracts inhibited the action of the 
enzyme catalyst glycogenolysis. This was also discovered by Adrini et al. (2015), Singh and Gupta (2015); Mahmoud et al. (2018); He et al. (2019).

Overall, the effectiveness of IC in reducing the rate of glycogenolysis shows that it is able to improve metabolic balance (Antosiewicz et al. 2006; Peinado et al. 2012) related to energy regulation and homeostasis (Roland et al. 2016). From the results of this study, metabolic balance and the achievement of homeostasis with or without IC administration causes no significant difference in glucose levels between treatment groups. Therefore, this shows that glucose is an important buffer for body fluids (Picker et al. 2013; Lee et al. 2014; Loyau et al. 2014), and maintains blood viscosity (Renaudeau et al. 2012; Ma et al. 2014; Roland et al. al 2016; Mushawwir et al. 2018), as well as the osmotic pressure of dissolving cells (Mushawwir et al. 2011; Royer et al. 2016; Hernawan et al. 2017).

\section{Glycolysis pathway}

The effect of various levels of IC on the metabolite concentrations of the glycolysis pathway in the Pasundan bulls is shown in Table 3 .

Glycolysis is a biochemical pathway to degrade glucose into simpler compounds, namely pyruvic, acetyl co-A, and citric acid. This pathway is essential for providing energy precursors. However, the main route for the provision of these energy precursors in ruminants is gluconeogenesis.

The results of this study are expected to comprehensively explain the biochemical phenomena that occur in supplying energy for Pasundan bulls. Therefore, the results show that the rate of glycolysis is highest in the Pasundan bulls group without chitosan administration, as shown in Table 3. This conclusion is made due to the high glucose breakdown products in this group. In table 3, the lactate levels in the Pasundan bulls group without IC administration were significantly higher $(\mathrm{P}<0.05)$, precisely $26.89 \mathrm{mg} / \mathrm{dL}$, compared to Pasundan bulls with 400-500 ppm administration. The same phenomenon was also observed in the metabolite D-glyceraldehyde 3-P, including the activity of the glucose 6-P Dehydrogenase enzyme.

This is similar to the results in Table 1, where the glucose levels of Pasundan bulls were not significantly different $(\mathrm{P}>0.05)$ in all treatment groups. Therefore, an interesting result in Table 2 is an increase in pyruvic acid levels with increasing levels of IC administration. Their pyruvic level at $500 \mathrm{ppm}$ IC was the highest $(\mathrm{P}<0.05)$, precisely $25.76 \mathrm{mg} / \mathrm{dL}$ among all treatment groups. The same phenomenon was observed in the citric acid profile. Therefore, it can be concluded that the increase in pyruvic and citric acid levels is not accompanied by an increase in glucose levels. Furthermore, pyruvic and citric acid levels are not dependent on glycolysis. These results strengthen the theory that IC is able to stimulate an increase in gluconeogenesis. Researchers have previously observed increasing levels of pyruvic and citric acid with rising rates of gluconeogenesis (Silver et al. 2012; Pickler et al. 2013; Cayan and Erener 2015; Eyng et al. 2015). The investigations by Cai et al. (2014) showed that there is an increase in lipolysis through the gluconeogenesis pathway which influences the pyruvic acid increase in plasma. Similar results were observed by Tapola et al. (2008), that the rise in pyruvic acid due to chitosan occurs with the degradation of cholesterol, forming acetyl Co-A and pyruvic.

Table 2. Liver metabolic by glycogenolysis pathway in Pasundan cattle without and with fed Irradiated Chitosan (IC)

\begin{tabular}{lccccc}
\hline \multirow{2}{*}{ Metabolites } & \multirow{2}{*}{$\mathbf{0 ~ p p m ~ I C ~}$} & \multicolumn{3}{c}{ IC (ppm) } \\
\cline { 3 - 6 } & & $\mathbf{3 5 0}$ & $\mathbf{4 0 0}$ & $\mathbf{4 5 0}$ & $\mathbf{5 0 0}$ \\
\hline Glycogen (mg/dL) & $0.97 \pm 0.01^{\mathrm{a}}$ & $1.13 \pm 0.16^{\mathrm{a}}$ & $1.16 \pm 0.12^{\mathrm{a}}$ & $1.32 \pm 0.21^{\mathrm{b}}$ & $1.48 \pm 0.13^{\mathrm{c}}$ \\
Glycogen phosphorylase (IU/dL) & $0.43 \pm 0.01^{\mathrm{a}}$ & $0.35 \pm 0.02^{\mathrm{ab}}$ & $0.32 \pm 0.02^{\mathrm{b}}$ & $0.30 \pm 0.01^{\mathrm{bc}}$ & $0.26 \pm 0.01^{\mathrm{c}}$ \\
Glucose 1-phosphate (IU/dL) & $0.42 \pm 0.01^{\mathrm{a}}$ & $0.37 \pm 0.01^{\mathrm{b}}$ & $0.32 \pm 0.01^{\mathrm{b}}$ & $0.35 \pm 0.02^{\mathrm{c}}$ & $0.21 \pm 0.01^{\mathrm{d}}$ \\
Phosphoglucomutase (IU/dL) & $0.47 \pm 0.01^{\mathrm{a}}$ & $0.43 \pm 0.03^{\mathrm{a}}$ & $0.38 \pm 0.02^{\mathrm{b}}$ & $0.33 \pm 0.02^{\mathrm{c}}$ & $0.24 \pm 0.02^{\mathrm{d}}$ \\
Glucose 6-phosphate (mg/dL) & $0.34 \pm 0.02^{\mathrm{a}}$ & $0.27 \pm 0.02^{\mathrm{a}}$ & $0.31 \pm 0.03^{\mathrm{a}}$ & $0.23 \pm 0.01^{\mathrm{b}}$ & $0.20 \pm 0.01^{\mathrm{b}}$ \\
Glucose 6-phosphate (IU/dL) & $0.31 \pm 0.01^{\mathrm{a}}$ & $0.31 \pm 0101^{\mathrm{a}}$ & $0.34 \pm 0.02^{\mathrm{a}}$ & $0.34 \pm 0.02^{\mathrm{b}}$ & $0.22 \pm 0.01^{\mathrm{b}}$ \\
Glucose (mg/dL) & $73.53 \pm 2.53^{\mathrm{a}}$ & $72.95 \pm 3.21^{\mathrm{a}}$ & $72.82 \pm 3.05^{\mathrm{a}}$ & $71.92 \pm 2.27^{\mathrm{a}}$ & $72.76 \pm 2.03^{\mathrm{a}}$ \\
\hline
\end{tabular}

Note: Values are means \pm Standard Error; IC: Irradiated Chitosan, ${ }^{\mathrm{a}, \mathrm{b}}$ Averages within a row having different superscripts are significantly different $(\mathrm{p}<0.05)$

Table 3. Liver metabolite levels during the glycolysis pathway in Pasundan cattle with and without Irradiated Chitosan (IC)

\begin{tabular}{|c|c|c|c|c|c|}
\hline \multirow{2}{*}{ Metabolite } & \multirow{2}{*}{ O ppm IC } & \multicolumn{4}{|c|}{ IC (ppm) } \\
\hline & & 350 & 400 & 450 & 500 \\
\hline Pyruvic acid (mg/dL) & $19.83 \pm 1.12^{\mathrm{a}}$ & $20.04 \pm 1.09^{\mathrm{a}}$ & $21.72 \pm 1.07^{\mathrm{ab}}$ & $23.64 \pm 1.03^{b}$ & $25.76 \pm 2.06^{\mathrm{c}}$ \\
\hline Lactate $(\mathrm{mg} / \mathrm{dL})$ & $26.89 \pm 1.07^{\mathrm{a}}$ & $25.79 \pm 2.05^{\mathrm{a}}$ & $21.04 \pm 1.05^{\mathrm{b}}$ & $18.15 \pm 1.05^{\mathrm{c}}$ & $15.91 \pm 1.05^{\mathrm{d}}$ \\
\hline D-Glyceraldehyde 3-P (IU/dL) & $2.83 \pm 0.03^{\mathrm{a}}$ & $2.76 \pm 0.01^{\mathrm{a}}$ & $2.02 \pm 0.01^{\mathrm{b}}$ & $1.77 \pm 0.02^{\mathrm{c}}$ & $1.54 \pm 0.03^{\mathrm{c}}$ \\
\hline Glucose 6-P Dehydrogenase (IU/dL) & $2.86 \pm 0.12^{\mathrm{a}}$ & $2.25 \pm 0.13^{\mathrm{a}}$ & $1.79 \pm 0.11^{\mathrm{ab}}$ & $1.33 \pm 0.12^{\mathrm{b}}$ & $1.23 \pm 0.11^{\mathrm{b}}$ \\
\hline Citric Acid & $1.11 \pm 0.07^{\mathrm{a}}$ & $1.14 \pm 0.10^{\mathrm{a}}$ & $1.46 \pm 0.10^{\mathrm{a}}$ & $2.06 \pm 0.10^{\mathrm{b}}$ & $2.87 \pm 0.06^{\mathrm{c}}$ \\
\hline
\end{tabular}

Note: Values are means \pm Standard Error; IC: Irradiated Chitosan, a,b Averages within a row with different superscripts are significantly different $(\mathrm{p}<0.05)$ 
Table 4. Plasma Biochemistry Related Liver Metabolism in Pasundan cattle with and without Irradiated Chitosan (IC)

\begin{tabular}{|c|c|c|c|c|c|}
\hline \multirow{2}{*}{ Plasma biochemistry } & \multirow{2}{*}{0 ppm IC } & \multicolumn{4}{|c|}{ IC (ppm) } \\
\hline & & 350 & 400 & 450 & 500 \\
\hline Glutamate oxaloacetate transaminase/GOT (IU/dL) & $61.68 \pm 2.14^{\mathrm{a}}$ & $60.37 \pm 3.06^{\mathrm{a}}$ & $57.83 \pm 2.01^{\mathrm{b}}$ & $56.66 \pm 3.01^{b}$ & $52.26 \pm 2.02^{\mathrm{c}}$ \\
\hline Glutamate pyruvite transaminase/GPT (IU/dL) & $57.78 \pm 1.24^{\mathrm{a}}$ & $54.53 \pm 1.63^{\mathrm{b}}$ & $52.78 \pm 1.05^{\mathrm{c}}$ & $49.31 \pm 1.13^{\mathrm{d}}$ & $49.85 \pm 1.27^{\mathrm{e}}$ \\
\hline 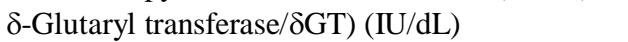 & $42.26 \pm 2.13^{\mathrm{a}}$ & $42.04 \pm 2.34^{\mathrm{a}}$ & $38.52 \pm 2.18^{b}$ & $37.26 \pm 2.52^{\mathrm{b}}$ & $35.95 \pm 2.31^{\mathrm{c}}$ \\
\hline Creatine $(\mathrm{mg} / \mathrm{dL})$ & $42.52 \pm 2.51^{\mathrm{a}}$ & $41.39 \pm 2.25^{\mathrm{a}}$ & $39.24 \pm 2.38^{b}$ & $36.18 \pm 2.29^{c}$ & $33.85 \pm 2.61^{\mathrm{d}}$ \\
\hline Creatine kinase/CK (mg/dL) & $31.09 \pm 3.31^{\mathrm{a}}$ & $29.93 \pm 3.04^{\mathrm{a}}$ & $27.27 \pm 2.12^{\mathrm{b}}$ & $26.84 \pm 2.24^{\mathrm{b}}$ & $25.74 \pm 2.15^{\mathrm{c}}$ \\
\hline
\end{tabular}

\section{Plasma biochemistry}

The effect of various levels of IC on the plasma biochemistry concentrations related to liver metabolism in Pasundan bulls is shown in Table 4. The results in Table 4 show that the levels of the transaminase enzymes, GT, creatine, and creatine kinase were significantly higher ( $\mathrm{P}$ $<0.05$ ) in the group without IC administration, compared to the treatment groups. Therefore, IC is very effective in reducing the levels of these compounds.

The liver is one of the organs most affected by metabolic activity. One of the natural mechanisms of the liver is damaged to its cells due to free radicals of metabolic activity, which causes liver damage in livestock. Free radicals in liver cells result in the failure of carbohydrate metabolism, fat, and protein synthesis, ultimately resulting in the death of liver cells and tissue (Dhanasekaran et al. 2011; Vizzotto et al. 2015). Furthermore, the negative impact of high metabolic rate is oxidative stress, indicated by increased fat peroxidation and decreased enzymatic and non-enzymatic antioxidants (Ippolito et al. 2014; Xu et al. 2015;).

Damage to liver cells is indicated by damage to their cell membrane, which leads to cell death. This results in the migration of liver enzymes into the vascular system. Consequently, the levels of the enzyme transaminase, both SGOT and SGPT increase significantly ( $\mathrm{P}<0.05)$, which occurred in the blood plasma of the Pasundan bulls group without IC administration.

The metabolic activity has an impact on liver cells, and causes oxidative damage to lipids and lipoproteins, which are components of cells (Tanuwiria, 2011; Roland et al. 2016; Vizzoto et al. 2015). Several studies have shown that oxidative damage causes the emergence of free radicals, which in turn, damages lipid structure (Tian et al. 2016; Damaziak et al. 2017; Hernawan et al. 2017), enzymes (Burdick et al. 2011), nucleic acids and proteins (Carrol et al. 2016) as well as cell and DNA damage (Cai et al. 2014; Shin et al. 2010; Holt et al. 2019).

IC is effective in reducing or overcoming cell death, both as a direct effect of aflatoxins, as well as an indirect impact, especially in increasing free radicals that cause cell death. The effectiveness of irradiated chitosan in preventing damage to liver cells is shown to be optimum at $500 \mathrm{ppm}$ IC, followed by a significant decrease $(\mathrm{P}<0.05)$ in AST levels of 52.26 and SGPT 49.85, as shown in Table 4. SGOT and SGPT blood plasma in the Pasundan bulls group decreased at 350-450 ppm IC administration, including the group without IC administration. Therefore, the migration of SGOT and SGPT into the blood vessel system due to damage of liver cells decreased significantly.

The results of this study prove that irradiated chitosan with a molecular weight of $30-50 \mathrm{kD}$ successfully interacted and generated molecular signals in cells. In addition to signals that stimulate cell repair, irradiated chitosan can counteract the negative impact of free radicals, especially from reactive oxygen species (ROS).

Previous researchers have reported the biochemical mechanism of chitosan in preventing, overcoming, and repairing liver cells. Carroll et al. (2016) and $\mathrm{He}$ et al. (2019) demonstrated its ability to prevent ROS signaling through the activation of Cyclic Guanine MonophospatAdenyn Monophospat Synthase (cGAS) and Stimulator of Interferon Genes (STING) in dendrite cells. Activation of cGAS-STING consequently induces the activation of interferon dependent type-1 (I IFN-dependent), thereby enabling the dendrite cells to become active. Furthermore, Blaauboer et al. (2015) and Cai et al. (2014) reported that the activation of dendrite cells increased the polarization response of T-helper 1 (TH1) cells protein. Th1 activation increases gamma interferon (IFN g), which stimulates immunoglobulin $\mathrm{G}(\mathrm{IgG})$ in the cytoplasm. In addition, enriched signal pathways help to prevent cell damage (Bueter et al. 2014).

The impact of IC administration in preventing cellular damage is shown by the ability of chitosan to activate ATP realists (Gehrke et al. 2013), which stimulate the activation of nuclear protein receptors 3 (NLRP3 inflammasome) (Lin et al. 2014). The signal from NLRP3 stimulates the expression of the interleukin-1 $\beta$ (IL-1 $\beta$ ) and interferongamma (IFN $\gamma$ ) genes. Increased levels of interleukin-1 $\beta$ (IL-1 $\beta$ ) and interferon-gamma (IFN $\gamma$ ) prevent ROS from inhibiting Cyclic Guanin Monophospat-Adenyn Monophospat Synthase (cGAS) and Stimulator of Interferon Genes (STING) (Dubensky et al. 2013; Ippolito et al. 2014; Tanuwiria et al. 2020). Therefore, the damage to liver cells is effectively treated with IC.

This study shows that IC reduces the activity of glycogenolysis and glycolysis, but is accompanied by improvements in the biochemical conditions of liver cells. This is favorable for the metabolism of Pasundan bulls which support the achievement of higher performance (growth and reproduction). 


\section{ACKNOWLEDGEMENTS}

The author expresses gratitude to the Directorate of Higher Education of the Republic of Indonesia, for funding this research, through a multi-year basic scheme. They are also grateful to the Head of the Laboratory of Animal Physiology and Biochemistry, Biolabo and Quartizlab staffs, which have supported and allowed the use of some equipment analysis. All authors have equally contributed to the preparation, implementation, and writing of this research article.

\section{REFERENCES}

Aamir HM, Babiker SA, Youssif GM, Hassan YA. 2010. Phenotypic characterization of Sudanese Kenana cattle. Res J Anim Vet Sci 5: 43-47.

Abdullah MAN, Noor RR, Martojo H, Solihin DD, Handiwirawan E. 2007. The phenotypic variability of Aceh cattle at Nanggroe Aceh Darussalam. J Indon Trop Anim Agric 32: 11-21.

Adrial. 2010. The potential of Pesisir cattle and its development in West Sumatra. Jurnal Litbang Peteternakan 29: 66-72. [Indonesian]

Adriani L, Abun, Mushawwir A. 2015. Effect of dietary supplementation of Jengkol (Pithecellobium jiringa) skin extract on blood biochemistry and gut flora of broiler chicken. Intl J Poultry Sci 14: 407-410.

Adriani L, Mushawwir A. 2020. Correlation between blood parameters, physiological and liver gene expression levels in native laying hens under heat stress. IOP Conf Ser Earth Environ Sci 466: 012015. DOI: 10.1088/1755-1315/466/1/012015.

Allen JD, Hall LW, Collier RJ, Smith JF. 2015. Effect of core body temperature, time of day, and climate conditions on behaviora patterns of lactating dairy cows experiencing mild to moderate heat stress. J Dairy Sci 98: 118-27.

Ao X, Yoo JS, Lee H, Jang HD, Wang J, Zhou TX. 2020. Effects of fermented garlic powder on production performance, egg quality, blood profiles and fatty acid composition of egg yolk in laying hens. J Anim Sci 23: 786-791.

Araujo APC, Venturelli BC. Santos MCB, Gardinal R, Consolo NRB Calomeni GD, Freitas JE, Barletta RV, Gandra JR, Paiva PG, Renno FP. 2015. Chitosan affects total nutrient digestion and ruminal fermentation in Nellore steers. Anim Feed Sci Technol 206: 114-118.

Azis A, Abbas H, Heryandi Y, Kusnadi E 2012 Thyroid hormone and blood metabolites concentrations of broiler chickens subjected to feeding time restriction. Med Pet 35: 32-37

Blaauboer SM, Mansouri S, Tucker HR, Wang HL, Gabrielle VD, Jin L. 2015. The mucosal adjuvant cyclic di-GMP enhances antigen uptake and selectively activates pinocytosis-efficient cell in vivo. eLife 4: 125.

Bueter CL, Lee CK, Wang JP, Ostroff GR, Specht CA, Levitz SM. 2014 Spectrum and mechanism of inflammasome activation by chitosan. $J$ Immunol 192: 5943-5951.

Burdick NC, Carroll JA, Randel R, Willard S, Vann R, Chase CC, Lawhon S, Hulbert LE, Welsh JT. 2011. Influence of temperament and transportation on physiological and endocrinological parameters in bulls. Livestock Sci 139: 213-221.

Cai X, Chiu YH, Chen ZJ. 2014. The cGAS-cGAMP-STING Pathway of Cytosolic DNA Sensing and Signaling. Mol Cell 54: 289-296.

Carrol EC, Jin L, Mori A, Wolf MN, Oleszycka E, Moran HBT, Mansouri S, McEntee CP, Lambe E, Agger EM, Andersen P, Cunningham C, Hertzog P, Fitzgerald KA, Bowie AG, Lavelle EC. 2016. The vaccine adjuvant chitosan promotes cellular immunity via dna sensor CgasSTING-dependent induction of Type I interferons. Immunity 44: 112.

Cayan H, Erener G. 2015. Effect of Olive leaf (Olea europaea) powder on laying hens performance, egg quality and egg yolk cholesterol levels. Asian-Australas J Anim Sci 28: 538-543.

Damaziak K, Riedel J, Gozdowski D, Niemiec J, Siennicka A, D. 2017 Productive performance and egg quality of laying hens fed diets supplemented with garlic and onion extracts. J Appl Poult Res 26: 337-349.
Darwis D, Puspitasari T, Iramani D, Susilowati S, Pangerteni DS. 2014. Preparation of low molecular weight chitosan by radiation and its application for plant growth promoter. IAEA Tecdoc Series: Radiation processed materials in products from polymers for agricultural applications. IAEA, Vienna.

Department of Animal Husbandry. 2013. Characteristics of Pasundan cattle. Department of Animal Husbandry of West Java Province, Indonesia. [Indonesian]

Dhanasekaran D, Shanmugapriya S, Thajuddin N, Panneerselvam A. 2011. Aflatoxins and aflatoxicosis in human and animals. In: Guevara-Gonzalez RG (ed.). Aflatoxins Biochemistry and Molecular Biology. IntechOpen, UK.

Dubensky TW, Kanne DB, Leong ML. 2013. Rationale, progress and development of vaccines utilizing STING-activating cyclic dinucleotide adjuvants. Ther Adv Vaccines 1: 131-143.

Eyng C, Murakami AE, Santos TC, Silveira TGV, Pedrosa TB, Lourenco DAL. 2015. Immune responses in broiler chicks fed propolis extraction residue-supplemented diets. Asian-Australas J Anim Sci 28: $135-142$

Fabris TF, Laporta J, Corra FN. 2017. Effect of nutritional immunomodulation and heat stress during the dry period on subsequent performance of cows. J Dairy Sci 100: 6733-6742.

Gehrke N, Mertens C, Zillinger T, Wenzel J, Bald T, Zahn S, Tuting T, Hartmann G, Barchet W. 2013. Oxidative Damage of DNA Confers Resistance to Cytosolic Nuclease TREX1 Degradation and Potentiates STING-Dependent Immune Sensing. Immunity 39: 482495.

Gray LR, Sultana MR, Rauckhorst AJ. 2015. Hepatic mitochondrial pyruvate carrier 1 is required for efficient regulation of gluconeogenesis and whole-body glucose homeostatis. Cell Metabolism 22: 669-681.

He ML, Yang WZ, You JS, Chaves AV, Mir PS, Benchaar C, McAllister TA. 2019. Effects of garlic oil on fatty acid accumulation and glycerol-3-phosphate dehydrogenase activity in differentiating adipocytes. J Anim Sci 22: 1686-1692.

Hecker JG and McGarvey M 2011 Heat shock proteins as biomarkers for the rapid detection of brain and spinal cord ischemia: a review and comparison to other methods of detection in thoracic aneurysm repair. Cell Stress Chaperones 16: 119-131.

Hernawan E, Adriani L, Mushawwir A, Cahyani C, Darwis D. 2017. Effect of dietary supplementation of chitosan on blood biochemical profile of laying hens. Pak J Nutr 16: 696-699.

Holt PS, Vaughn LE, Gast RK. 2019. Flow cytometric characterization of Peyer's patch and cecal tonsil T lymphocytes in laying hens following challenge with Salmonella enterica serovar enteritidis. Vet Immunol Immunopathol 133: 276-281.

Ippolito DL, Lewis JA, Yu C, Leon LR, Stallings JD. 2014. Alteration in circulating metabolites during and after heat stress in the conscious rat: potential biomarkers of exposure and organ-specific injury. BMC Physiol 14: 23-29.

Kamil KA, Latipudin D, Mushawwir A, Rahmat D, Balia RL. 2020. The Effects of ginger volatile oil (GVO) on the metabolic profile of glycolytic pathway, free radical and antioxidant activities of heatstressed cihateup duck. Intl J Adv Sci Eng Inform Technol 10: 12281233.

Khan S, Anwar K, Kaleem K, Saeed A, Nabi H, Hayat A, Ahmad Z, Hayan F, Safirullah. 2015. Study of phenotypic and morphometric characteristics of Achai cattle at Livestock Research and Development Station Dir (Lower), Pakistan. Pak J Nutr 14: 201-203.

Kusmayadi A, Adriani L, Abun, Muhctaridi, Tanuwiria UH. 2018. The effect of solvents and extraction time on total xanthone and antioxidant yields of mangosteen peel (Garcinia mangostana L.) extract. Drug Invention Today 10: 2572-2576.

Lee DH, Lim SR, Ra SS, Kim JD. 2014. Effects of dietary garlic powder on growth, feed utilization and whole-body composition change in fingerling sterlet sturgeon, Acipenser ruthenus. Asian-Australas J Anim Sci 27: 1419-1429.

Lin YC, Lou PJ, Young TH. 2014. Chitosan as an adjuvant-like substrate for dendritic cell culture to enhance antitumor effect. Biomaterials 35 : 8867-8875.

Loyau T, Metayer-Coustard S, Berri C, Crochet S, Cailleau-Audouin S, Sannier M, Chartrin P, Praud C, Hennequet-Antier C, Rideau N, Courousse N, Mignon-Grasteau, Everaert N, Duclos MJ, Yahav S, Tesseraud S, Collin A. 2014. Thermal manipulation during embryogenesis has longterm effects on muscle and liver metabolism 
in fast-growing chickens. PLoS One 9: e105339. DOI: 10.1371/journal.pone.0105339.

Ma X, Lin Y, Zhang H, Chen W, Wang S, Ruan D, Jiang Z. 2014. Heat stress impairs the nutritional metabolism and reduces the productivity of egg-laying ducks. Anim Reprod Sci 145: 182-190.

Mahmoud ZK, Gharaibeh SM, Zakaria HA, Qatramiz AM. 2018. Garlic (Allium sativum) supplementation: influence on egg production, quality, and yolk cholesterol level in layer hens. J Anim Sci 23: 15031509.

Mingoti RD, Freitas JE, Gandra JR, Gardinal R, Calomeni GD, Barletta RV, Vendramini THA, Paiva PG, Renno FP. 2016. Dose response of chitosan on nutrient digestibility, blood metabolites abd lactation performance in Holstein dairy cows. Livestock Sci 187: 35-39.

Monteiro AP, Guo JR, Weng XS. 2016. Effect of maternal heat stress during the dry period on growth and metabolism of calves. J Dairy Sci 99: 3896-3907.

Moreno KX, Moore CL, Burgess SC. 2019. Production of hyperpolarized ${ }^{13} \mathrm{CO}_{2}$ from $[1-13 \mathrm{C}]$ pyruvate in perfused liver does reflect total anaplerosis but is not a reliable biomarker of glucose production. Animal 23: 23-29.

Mushawwir A, Adriani L, Kamil KA. 2011. Prediction models for olfactory metabolic and sows\% Rnareticulocyt (Rnart) by measurement of atmospheric ammonia exposure and microclimate level. J Indon Trop Anim Agric 36: 14-20.

Mushawwir A, Tanuwiria UH, Kamil KA, Adriani L, Wiradimadja R, Suwarno N. 2018. Evaluation of haematological responses and blood biochemical parameters of heat-stressed broilers with dietary supplementation of Javanese ginger powder (Curcuma xanthorrhiza) and garlic extract (Allium sativum). Intl J Poultry Sci 17: 452-458.

Mushawwir A, Yong YK, Adriani L, Hernawan E, Kamil KA. 2010. The fluctuation effect of atmospheric ammonia $\left(\mathrm{NH}_{3}\right)$ exposure and microclimate on hereford bulls hematochemical. J Indon Trop Anim Agric 35: 232-238.

Nugraha DD, Setyowati EY, Suwarno N. 2016. Quantitative Characteristics of Pasundan cattle in Village Farming. [Thesis]. Padjajaran University, Bandung. [Indonesian]

Odore R, Badino P, Re G, Barbero R, Cuniberti B, D'Angelo A, Girardi C, Fraccaro E, Tarantola M. 2011 Effects of housing and short-term transportation on hormone and lymphocyte receptor concentrations in beef cattle. Res Vet Sci 90: 341-345.

Paiva PG, de Jesus EF, Valle TAAD, Del Almeida GF, Costa AGBVB, Consentini CEC, Zanferari F, Takiya CS, da Silva Bueno CS, Renno FP. 2016. Effects of chitosan on ruminal fermentation, nutrient digestibility, and milk yield and composition of dairy cows. Anim Prod Sci 53: 231-236.

Pickler L, Breno C, Beirão B, Ricardo M, Hayashi J, Durau F, Lourenço M C, Caron L F and Santin E. 2013 Effect of sanguinarine in drinking water on Salmonella control and the expression of immune cells in peripheral blood and intestinal mucosa of broilers J Appl Poultry Res 22: 430-438

Qiu Y, Hu YL. 2018. Immunopotentiating effect of four chinese herbal polysaccharides administered at vaccination in chickens. Poultry Sci 86: $2530-2535$

Renaudeau D, Collin A, Yahav S, De Basilio V, Gourdine JL, Collier RL. 2012. Adaptation to hot climate and strategies to alleviate heat stress in livestock production. Animal 6: 707-728

Roland L, Drillich M, Klein-Jobstl D, Iwernes M 2016. Invited review: Influence of climatic conditions on the development, performance, and health of claves. J Dairy Sci 99: 2438-2445.
Roland L, Drillich M, Klein-Jobstl D, Iwernes M. 2016. Invited review: Influence of climatic conditions on the development, performance, and health of claves. J Dairy Sci 99: 2438-2452.

Royer EF, Barbé T, Guillou D, Rousselière Y, Chevaux E. 2016. Development of an oxidative stress model in weaned pigs highlighting plasma biomarkers' specificity to stress inducers. J Anim Sci 94: 48-53

Shin HS, Yoo1 JH, Min TS, Lee J, Choi CY. 2010. Effect of quercetin on the activity and mRNA expression of antioxidant enzymes and physiological responses in olive flounder (Paralichthys olivaceus) exposed to cadmium. Asian-Australasian J Anim Sci 23: 742-749.

Silver JT, Kowalchuk H, Noble EG. 2012. HSP70 mRNA temporal localization in rat skeletal myofibers and blood vessels post-exercise Cell Stress Chaperones 17: 109-120.

Singh CK, Gupta RK. 2015. First report of Meloidogyne javanica on ginger and Meloidogyne incognita on coriander in Jammu and Kashmir (India). J Hort Sci 6: 74-75.

Siskos AP, Jain P, Romisch-Margl W. 2017. Interlaboratory reproducibility of a targeted metabolomics platform for analysis of human serum and plasma. Anal Chem 89: 656-665.

Slimen B, Najar T, Ghram A, Abdrranna M. 2016. Heat stress effects on livestock: molecular, cellular and metabolic aspects, a review. J Anim Physiol Anim Nutr 100: 401-412.

Soisuwan K, Chauychuwong C. 2013 Effects of phytogenic feed additive with reduced dietary metabolizable energy and digestible essential amino acids on carcass yields and meat quality of Peking ducks. J Appl Sci Res 9: 6099-6102.

Sutarno, Setyawan AD. 2015. Genetic diversity of local and exotic cattle and their crossbreeding impact on the quality of Indonesian cattle. Biodiversitas 16: 327-354.

Sutarno, Setyawan AD. 2016. The diversity of local cattle in Indonesia and the efforts to develop superior indigenous cattle breeds. Biodiversitas 16: 275-295.

Tanuwiria UH, Mushawwir A. 2020. Hematological and antioxidants responses of dairy cow fed with a combination of feed and duckweed (Lemna minor) as a mixture for improving milk biosynthesis. Biodiversitas 21:4741-4746.

Tanuwiria UH, Santosa U, Yulianti AA, Suryadi U. 2011. The effect of organic-Cr dietary supplementation on stress response in transportstressed beef cattle. J Indon Trop Anim Agric 36: 97-103.

Tian H, Wang W, Zheng N. 2015. Identification of diagnostic biomarkers and metabolic pathway shifts of heat-stressed lactating dairy cows. J Proteomics 125: 17-28.

Tian H, Zheng N, Wang W. 2016. Integrated metabolomics study of the milk of heat-stressed lactating dairy cows. Sci Reprod 6: 24-28.

Valle TA, Paiva PG, Jesus EF, Almeida GF, Zanferari F, Costa AGBVB, Bueno IGS, Renno FP. 2017. Dietary chitosan improves nitrogen use and feed conversion in diets for mid-lactation dairy cows. Livestock Sci 201: 22-29.

Vizzotto EF, Fischer V, Thaler NA. 2015 Access to shade changes behavioral and physiological attributes of dairy cows during the hot season in the subtropics. Animal 9: 1559-1566.

Xu B, Chen M, Ji X. 2015. Metabolomic profiles reveal key metabolic changes in heat stress-treated mouse Sertoli cells. Toxicol in Vitro 29: 1745-1752

Yarrus LP, Settivari RS, Gowda NKS, Antoniou A, Ledoux DR, Rottinghaus GE. 2012. Effects of turmeric (Curcuma longa) on the expression of hepatic genes associated with biotransformation, antioxidant, and immune systems in broiler chicks fed aflatoxin. Poult Sci 88: 2620-2627. 